\title{
Antipredator and alarm reaction responses of silver catfish (Rhamdia quelen) juveniles exposed to waterborne ammonia
}

\author{
Paula Weber, Carina Vogel, Carla Lang and Bernardo Baldisserotto
}

Ammonia has relatively toxic effects on fish and other aquatic organisms. This study examined whether juvenile silver catfish exposed to alarm substances released by conspecifics and predators in water with different ammonia levels modify their behaviour in response to the perceived risk of predation. We used juvenile catfish that were naive to predators. The fish were raised from the larval stage in the laboratory and kept in 40-L aquaria at waterborne $\mathrm{NH}_{3}$ concentrations of $0,0.05,0.1$, or $0.2 \mathrm{mg} \mathrm{L}^{-1}$ for 10 days. The alarm substances used were predator odour and skin extract from conspecifics. The juveniles were transferred to 2-L aquaria for the antipredator and alarm reaction behavioural tests, which were performed on days 1, 5 and 10 after initial exposure to ammonia. The test aquaria contained a shelter at one end of the tank. The trials consisted of a 10-min prestimulus and a 10-min poststimulus observation period. The results of the study suggest that naive juvenile catfish are able to identify predators and skin extract from conspecifics by odour. In addition, waterborne $\mathrm{NH}_{3}$ levels modify the antipredator response of this species.

Amônia possui efeito relativamente tóxico em peixes e outros organismos aquáticos. Este estudo examinou se juvenis de jundiás modificam seu comportamento em resposta a percepção do risco de predação quando expostos a substâncias de alarme liberadas por conspecíficos e predadores em água com diferentes concentrações de amônia. Foram utilizados juvenis de jundiá nunca expostos a predadores. Os peixes foram criados em laboratório desde a fase larval e mantidos em aquários de 40-L contendo diferentes concentrações de $\mathrm{NH}_{3}: 0 ; 0,05 ; 0,1$ e $0,2 \mathrm{mg} \mathrm{L}^{-1}$ por 10 dias. As substâncias de alarme utilizadas foram odor de predador e extrato de pele de conspecíficos. Os juvenis foram transferidos para aquários de 2-L para realização dos testes para comportamento antipredador e resposta à substância de alarme, os quais foram realizados nos dias 1,5 e 10 a partir do início da exposição à amônia. $\mathrm{O}$ aquário teste continha um esconderijo em uma de suas extremidades. Foram feitas observações comportamentais 10-min pré-estímulo e 10-min pós-estímulo. Os resultados do estudo sugerem que juvenis de jundiá nunca expostos a predadores são capazes de identificar predadores e extrato de pele de conspecíficos pelo odor. Além disso, os níveis de $\mathrm{NH}_{3}$ na água alteram a resposta anti-predatória desta espécie.

Key words: Alarm substance, Behaviour, Predator odour, Skin extract, Un-ionised ammonia.

\section{Introduction}

Ammonia enters aquatic systems as a component of industrial and agricultural waste and of effluents. It is also produced by fish as a metabolic waste and may represent a major problem in fish farms. Ammonia diffuses easily through fish respiratory membranes and damages the gill epithelium (Miron et al., 2008). Consequently, it impairs gas exchange between the animal and the water, and it destabilises the osmoregulatory system (Wood, 2001). High waterborne ammonia levels also disrupt cerebral amino acid and energy metabolism and cause brain swelling (Walsh et al., 2007). The symptoms of ammonia poisoning in fish include hyperventilation, abnormal swimming, searching the surface, increasing ventilation rate, loss of balance, convulsions and, ultimately, death (Suski et al., 2007).

Ammonia has a major effect on the ability of white muscle to generate large amounts of energy quickly through anaerobic metabolism (Schulte et al., 1992). White muscle is known to be very susceptible to ammonia toxicity, and an increase in waterborne ammonia levels decreases the swimming performance of fish (Shingles et al., 2001; Tudorache et al., 2010). In an ecological context, reduced fast-start performance can affect escape and predation. Walker et al. (2005) showed that more rapid fast starts increase the probability of evading predators. Thus, a reduction in speed could lead to a higher risk of being captured by a predator. Consequently, predator species that are not affected by ammonia concentrations in the water, such as avian or mammalian predators, could have a significantly higher probability of successful predation on brown trout in ammoniapolluted freshwater (Tudorache et al., 2008).

The failure of prey to recognise and respond to a predator increases the probability of being captured during an encounter with a predator (Kiesecker et al., 1996). In freshwater fishes,

Universidade Federal de Santa Maria, Departamento de Fisiologia e Farmacologia, 97105-900 Santa Maria, Rio Grande do Sul, Brazil. paulaweberbio@gmail.com (PW), ruivinha.is@gmail.com (CV), carlangbio@gmail.com (CL), bbaldisserotto@hotmail.com (BB) 
the pattern of antipredator responses to detectable threat cues is influenced by the condition or state of the individual (Clark, 1994; Pollock et al., 2006) and by its life-history stage or body size (Willette, 2001; Marcus \& Brown, 2003; Harvey \& Brown, 2004; Elvidge et al., 2010). The chemical-sensory recognition of the predator by the prey may be essential if the predator is hidden or if it hunts from ambush. If the diet of the predator produces chemical cues that allow recognition of the predator by the prey, then these cues may provide important information to naive prey (Chivers et al., 1996). If a predator attacks a fish and causes substantial damage to the skin of the prey, specialised cells in the epidermis release a chemical called alarm substance that functions as an alarm signal. Other prey can detect the presence of the alarm substance through olfaction. The prey then displays a stereotyped pattern of predator avoidance behaviour. It thereby reduces the risk of predation (Scott et al., 2003). Studies with fishes of the superorder Ostariophysi, which includes the Cypriniformes, Characiformes, and Siluriformes, suggest that nitrogen oxides function as chemical alarm cues and that the nitrogen oxide functional group acts as the chief molecular trigger (Brown et al., 2000, 2003).

Silver catfish (Rhamdia quelen Quoy \& Gaimard, 1824) larvae respond to the skin extract of conspecifics and to the odour of the piscivorous Hoplias malabaricus (Kochhann et al., 2009). High waterborne ammonia levels affect common carp (Cyprinus carpio) swimming activity and feeding behaviour (IsraeliWeinstein \& Kimmel, 1998) and predatory behaviour and faststart performance in brown trout (Salmo trutta) (Tudorache et al., 2008). However, no previous studies have addressed the antipredator and alarm reaction responses of prey in an environment containing ammonia. Our hypothesis is that ammonia could affect the recognition of alarm substances released by conspecifics as well as the achievement of antipredator behavior. The aim of this study is to examine whether water contaminated with different ammonia levels affects the behaviour of silver catfish juveniles exposed to alarm substances released by conspecifics and to predator odour.

\section{Material and Methods}

Silver catfish juveniles were obtained from a population formed by artificial reproduction at the fish culture laboratory of the Universidade Federal de Santa Maria in southern Brazil and maintained at the Fish Physiology Laboratory of the same institution for $40 \mathrm{~d}$ prior to the experiments. The fish were kept in 40-L aquaria and fed three times daily with commercial food (Purina, 45\% crude protein). Water was siphoned from the aquaria once a day, and all waste was removed with suction.

\section{Exposure to ammonia}

Silver catfish juveniles were exposed to $\mathrm{NH}_{3}$ concentrations of $0.0,0.05,0.1$, and $0.2 \mathrm{mg} \mathrm{L}^{-1}$ for 10 days, 40 -L aquaria $(\mathrm{N}=10$, three replicates each). These levels were chosen because evenhigher levels did not induce mortality in silver catfish up to the $15^{\text {th }}$ day of exposure, but an increase in the level of waterborne $\mathrm{NH}_{3}$ proportionally reduced the growth rate in this species
(Miron et al., 2011). Approximately 20\% of the water in the aquaria was replaced daily and the level of un-ionised ammonia $\left(\mathrm{NH}_{3}\right)$ in the added water and the $\mathrm{pH}$ of the added water had previously been adjusted to the values determined by the experimental design. Behavioural tests were performed on days 1,5 and 10 after the beginning of $\mathrm{NH}_{3}$ exposure.

\section{Preparation of alarm substances}

The silver catfish skin extract was prepared according to the method of Brown \& Smith (1998). Individuals were selected and immediately killed with a blow to the head. The skin was removed from both sides of each fish (total $5 \mathrm{~g}$ ), rinsed with distilled water and placed in $50 \mathrm{~mL}$ of cold distilled water. The mixture of water and skin was homogenised and filtered through glass wool. The filtrate was diluted to a final volume of $400 \mathrm{~mL}$ with distilled water. The skin extract was stored in $25 \mathrm{~mL}$ samples at $-20^{\circ} \mathrm{C}$ prior to use. Distilled water was stored in $25-\mathrm{mL}$ samples at the same temperature for use as a control. To obtain predator odour, one specimen of $H$. malabaricus $(500 \mathrm{~g})$ was collected from the wild, quickly transported to the laboratory, kept in an $250-\mathrm{L}$ aquarium for three days at $24^{\circ} \mathrm{C}$ and fed five silver catfish juveniles ( $c a .5 .5 \mathrm{~cm}$ in length) daily. The predator was then transferred to a continuously aerated 20-L aquarium and kept in the aquarium for 15 hours. Water from the aquarium was stored in a refrigerator at $5^{\circ} \mathrm{C}$ and subsequently used as the predator odour stimulus. The H. malabaricus specimen was returned to the wild.

\section{Sampling and water analysis}

The water quality was analysed daily. Temperature $(25.0 \pm$ $\left.0.5^{\circ} \mathrm{C}\right)$ and dissolved oxygen $\left(7.35 \pm 0.06 \mathrm{mg} \mathrm{L}^{-1}\right)$ were measured using an oxymeter(YSI model Y5512). $\mathrm{pH}(7.5 \pm 0.5)$ was measured with a pH meter (400A Quimix). The levels of total ammonia ( $\mathrm{NH}_{3}$ $+\mathrm{NH}_{4}^{+}$) were determined according to Eaton et al. (2005), and the $\mathrm{NH}_{3}$ level was determined according to Piper et al. (1982).

\section{Experiment}

Juveniles $(3.2 \pm 0.2 \mathrm{~cm}$ and $1.1 \pm 0.1 \mathrm{~g})$ were transferred from the $40-\mathrm{L}$ aquaria to $2-\mathrm{L}$ polyethylene aquaria, where they remained isolated for $24 \mathrm{~h}$ before testing began. The experimental aquaria contained a marked midline and a shelter $(4 \times 4 \times 4 \mathrm{~cm})$ located at one end of the tank. Each behavioural observation $(\mathrm{N}=12$ fish for each test, in individual aquaria) lasted $20 \mathrm{~min}$. The observations were conducted using procedures similar to those in Kochhann et al. (2009). The trials consisted of a 10min prestimulus and a 10-min poststimulus observation period. A 1-mL stimulus sample (skin extract (SE), predator odour (PW) or distilled water (DW)) was added after the prestimulus period. The juveniles were fasted for 24 hours prior to the experiment. The time that the fish spent in the shelter and the number of midline crossings (an indication of locomotor activity) during the pre- and poststimulus periods were recorded as described by Scott et al. (2003).

The data are expressed as mean \pm SEM. The relationship between the measured parameters and waterborne ammonia was calculated using SigmaPlot 11.0 software. If no significant 
relationship was found, the homogeneity of variances among groups was tested using the Levene test. Because the variances were homoscedastic, the data were compared using two-way ANOVA(stimulus sample X waterborne ammonia levels) followed by the Tukey test. Statistica version 7.0 software was used for these tests. The minimum significance level was set at $\mathrm{P}<0.05$.

This study was approved by the Ethics Committee on Animal Experimentation of UFSM under registration number 25/2007.

\section{Results}

Overall mean time in the shelter and number of midline crossings by juvenile silver catfish during the $600 \mathrm{~s}$ (10 min) prestimulus period was $372 \pm 46.8 \mathrm{~s}$ and $10 \pm 3$, respectively. Nine per cent of the juveniles did not use the shelter, but there was no significant relationship between time in the shelter and number of midline crossings because only $11 \%$ of these juveniles that did not use the shelter showed higher number of midline crossings than the overall mean. These behavioural observations were not significantly altered by exposure to waterborne $\mathrm{NH}_{3}$.

Juvenile catfish exposed to PW spent significantly less time in the shelter than DW fish $(\mathrm{p}<0.05)$ (Fig.1). Overall, waterborne $\mathrm{NH}_{3}$ exposure increased two-fold the number of juveniles exposed to PW that increased the time spent in the shelter $(\mathrm{p}<$ 0.05 ), and the time spent in the shelter on day 1 by the juveniles exposed to $\mathrm{PW}$ increased in proportion to the level of waterborne $\mathrm{NH}_{3}$ (Fig. 1a; $r^{2}=0.81$ ). No such relationship was observed 5 or 10 days after $\mathrm{NH}_{3}$ exposure and the time spent in the shelter in these days was not affected significantly by PW compared to DW in juveniles exposed to waterborne $\mathrm{NH}_{3}$ (Fig. 1b, c). Exposure to PW increased significantly the number of line crossings $(\mathrm{p}<$ 0.05) (Fig. 2). The increase in waterborne $\mathrm{NH}_{3}$ levels did not changed significantly the number of line crossings after PW compared to DW (Fig. 2), but decreased significantly the number of juveniles that showed more line crossings after PW $(p<0.05)$. Silver catfish juveniles exposed to SE significantly reduced the time spent in the shelter, compared with DW fish, on day $1(\mathrm{p}<$ 0.05 ) but not on days 5 and 10 (Fig. 3 ).

Waterborne $\mathrm{NH}_{3}$ exposure did not change significantly the number of juveniles exposed to SE that increased the time spent in the shelter, but the time spent in the shelter by the juveniles exposed to SE on day 1 increased in proportion to the level of waterborne $\mathrm{NH}_{3}$ (Fig. $3 \mathrm{a} ; r^{2}=0.87$ ). This relationship was not observed 5 or 10 days after $\mathrm{NH}_{3}$ exposure (Fig. 3b, c). Exposure to SE did not change the number of line crossings on any of the experimental days (Fig. 4). The number of line crossings on day 10 increased in proportion to the level of waterborne $\mathrm{NH}_{3}$ (Fig. $4 \mathrm{c} ; r^{2}=0.76$ ), but no such relationship was observed on days 1 or 5 (Fig. 4a, b) and waterborne $\mathrm{NH}_{3}$ also did not change significantly the number of juveniles that showed more line crossings after SE.

\section{Discussion}

The typical antipredator behaviours of fish include reduction in activity and movement to the bottom (Wisenden et al., 2008), increasing use of shelters (Wisenden et al., 2010), shoal cohesion, avoiding alarm cues, changing the body shape and decreasing foraging (Chivers \& Smith, 1998). Lawrence \& Smith (1989) also recognise abrupt and fast movements, freezing and scanning as antipredator responses.

Silver catfish juveniles kept in water without $\mathrm{NH}_{3}$ and exposed to PW exhibited a significantly higher number of line
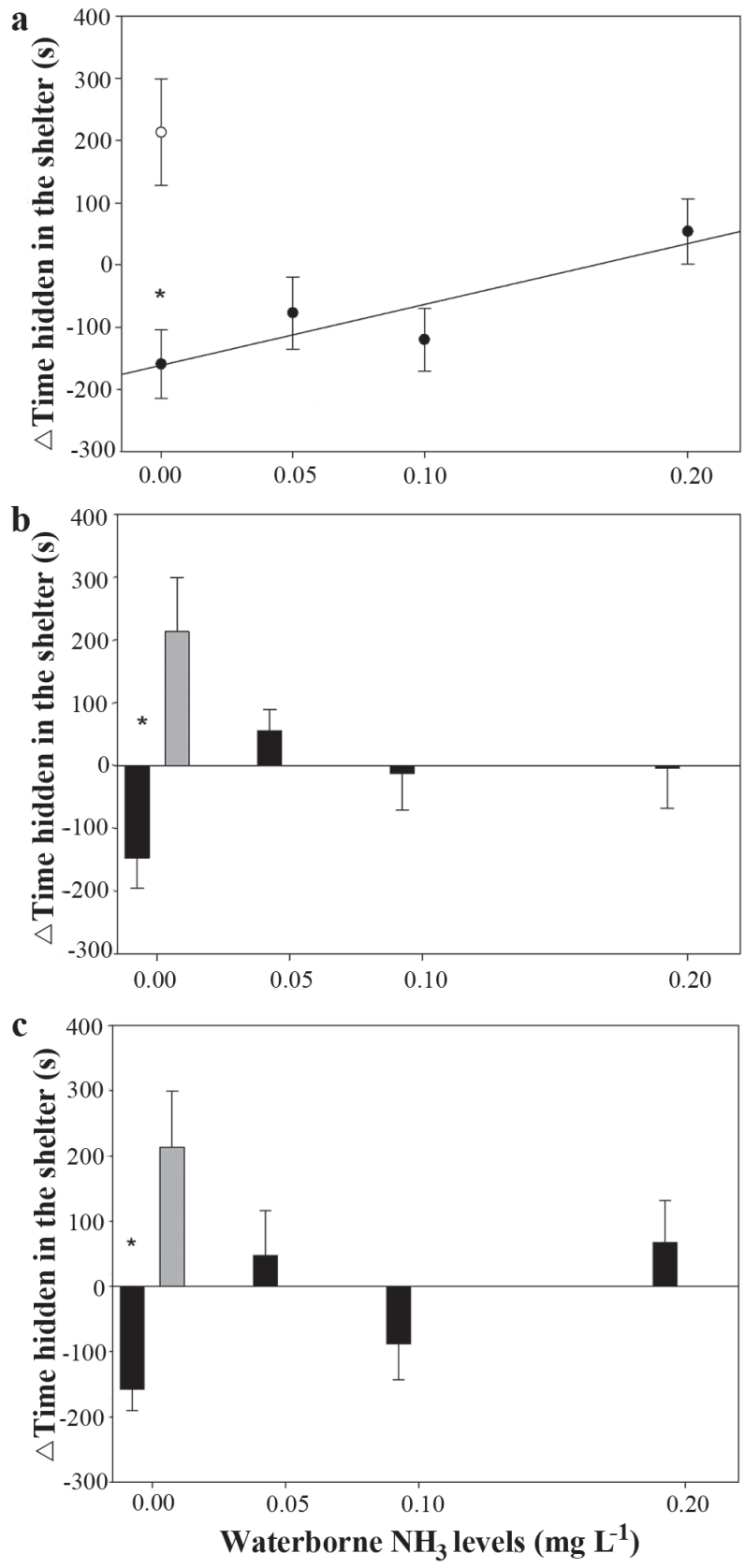

Fig. 1. Change in time spent in the shelter (mean $\pm \mathrm{SE}$ ) before and after exposure to predator odour (black dots or bars) and distilled water (grey bars or empty dots) on days 1 (a), 5 (b) and 10 (c) of exposure to different waterborne $\mathrm{NH}_{3}$ levels. * indicates a significant difference compared with distilled water $(\mathrm{p}<0.05) . \mathrm{A}: \mathrm{y}=-161.4+972.21 \mathrm{x}$, where $\mathrm{y}=\triangle$ time spent in the shelter $(\mathrm{s})$ and $\mathrm{x}=$ waterborne $\mathrm{NH}_{3}$ levels $\left(\mathrm{mg} \mathrm{L}^{-1}\right)$. 
crossings and spent less time in the shelter compared with unexposed fish. The juveniles exposed to SE from conspecifics also decreased the time spent in the shelter but did not change significantly the number of line crossings compared with unexposed fish. However, a previous study found that silver catfish larvae $(27 \mathrm{mg}$ ) exposed to SE or PW increased the time spent in the shelter and decreased the
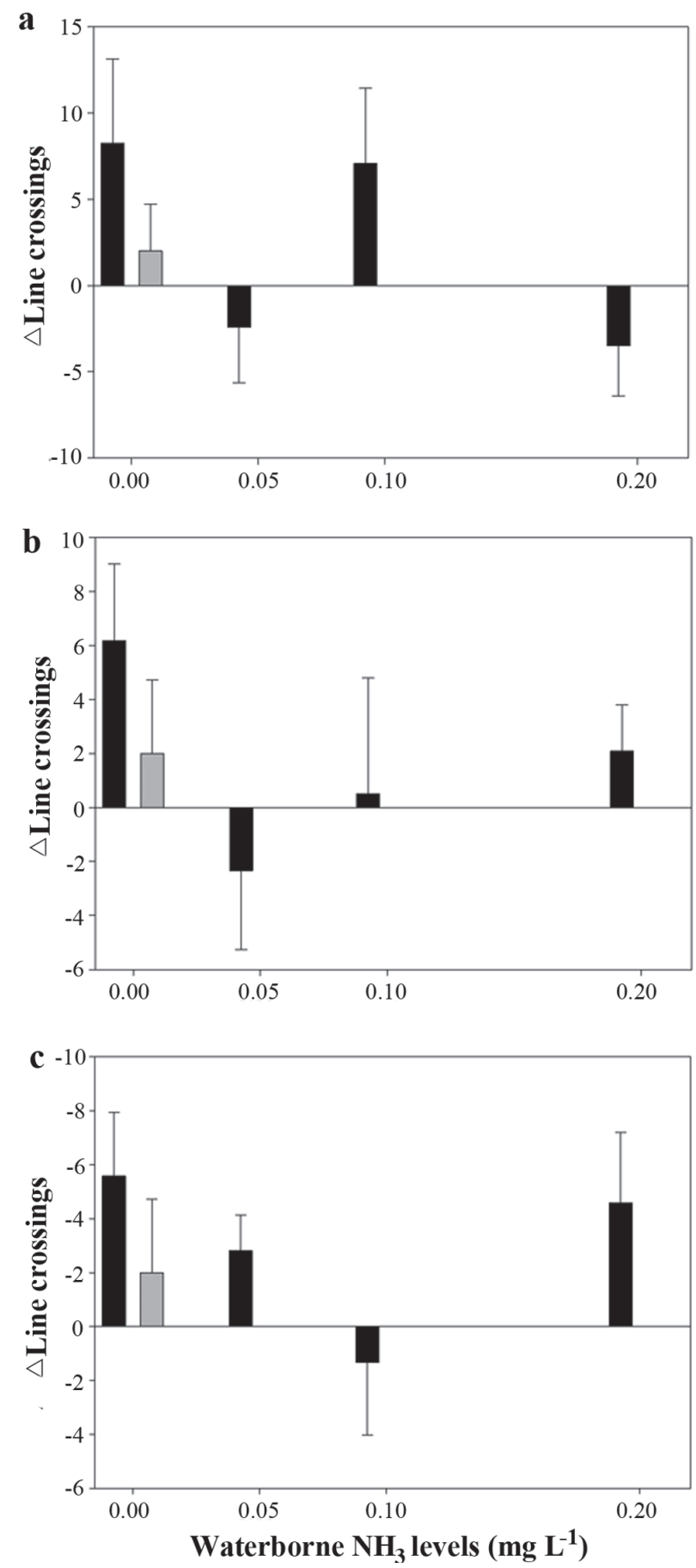

Fig. 2. Change in the number of line crossings (mean \pm SE) before and after exposure to predator odour (black bars) and distilled water (grey bars) on days 1 (a), 5 (b) and 10 (c) of exposure to different waterborne $\mathrm{NH}_{3}$ levels. number of line crossings (Kochhann et al., 2009), a usual antipredator response (Wisenden et al., 2008, 2010). These contrasting results might be a consequence of the different sizes of fish (larvae $0.027 \mathrm{~g}$, juveniles $1.1 \mathrm{~g}$ ) used in the two experiments. Apparently, the silver catfish larvae sought
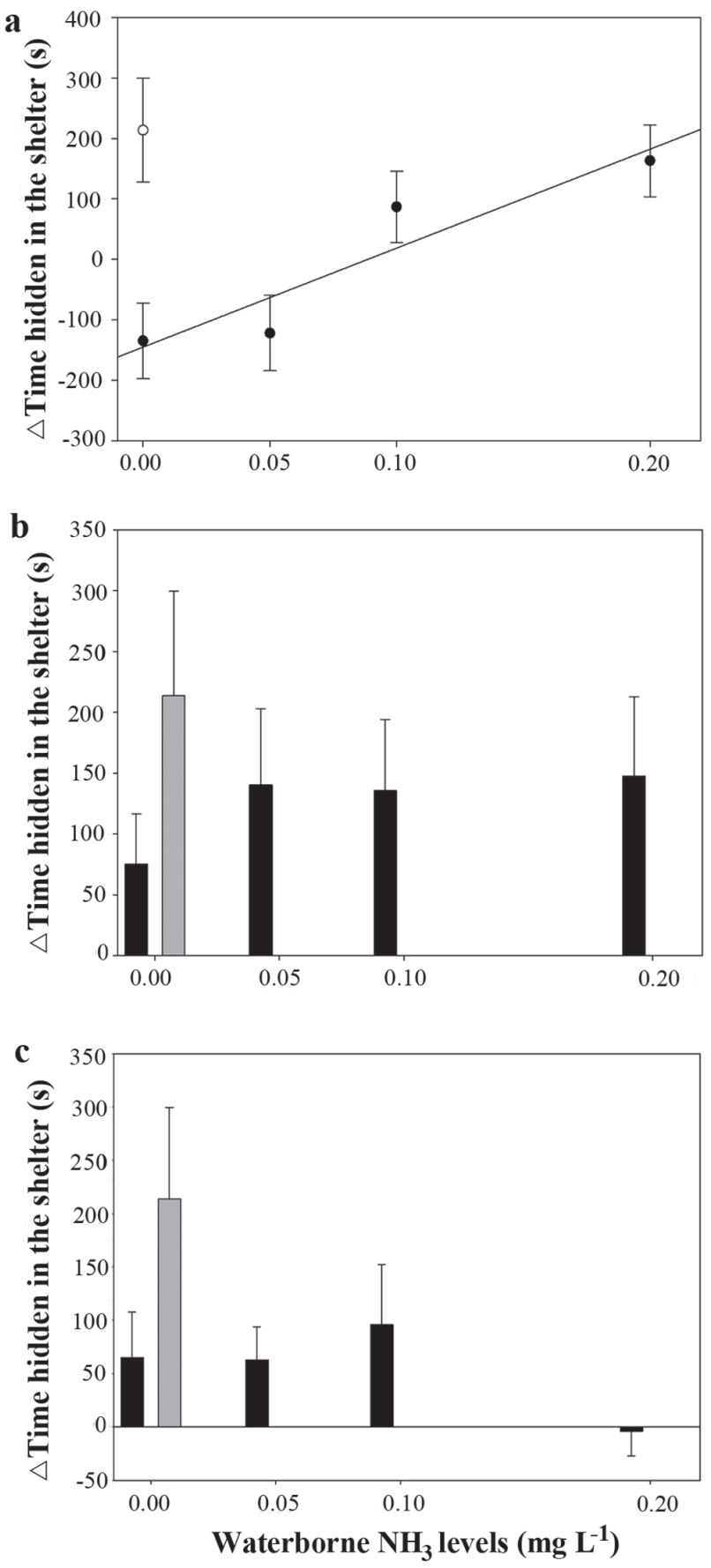

Fig. 3. Change in time spent in the shelter (mean \pm SE) before and after exposure to skin extract (black dots or bars) and distilled water (grey dots or bars) on days 1 (a), 5 (b) and 10 (c) of exposure to different waterborne $\mathrm{NH}_{3}$ levels. * indicates a significant difference compared with distilled water $(\mathrm{p}<0.05)$. A: $y=-144.94+1636.72 x$, where $y=\triangle$ time spent in the shelter (s) and $\mathrm{x}=$ waterborne $\mathrm{NH}_{3}$ levels $\left(\mathrm{mg} \mathrm{L}^{-1}\right)$. 
concealment because of their small body size, whereas the juveniles increased their amount of movement probably to avoid the PW stimulus. As locomotor activity in juveniles exposed to SE was similar, the fish probably stood somewhere else in the aquarium instead of the shelter. The Nile tilapia, Oreochromis niloticus, typically moves away (either rapidly or slowly) from the region in which an alarm substance was added, and this action precedes the freezing response (Barreto
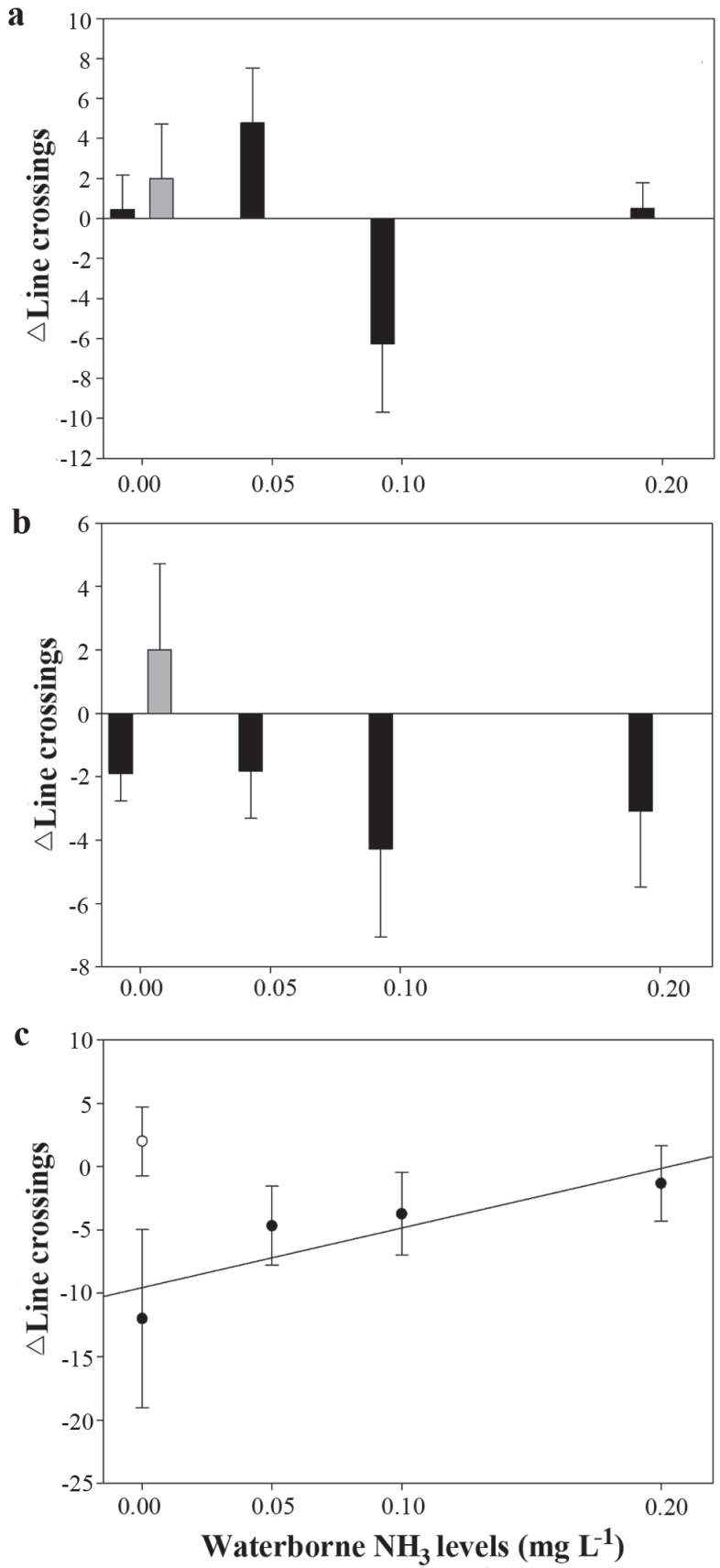

Fig. 4. Change in the number of line crossings (mean $\pm \mathrm{SE}$ ) before and after exposure to skin extract (black dots or bars) and distilled water (grey dots or bars) on days 1 (a), 5 (b) and 10 (c) of exposure to different waterborne $\mathrm{NH}_{3}$ levels. $\mathrm{C}$ : $\mathrm{y}=$ $9.54+47.01 \mathrm{x}$, where $\mathrm{y}=\triangle$ line crossings and $\mathrm{x}=$ waterborne $\mathrm{NH}_{3}$ levels $\left(\mathrm{mg} \mathrm{L}^{-1}\right)$. et al., 2010). Zebrafish, Danio rerio, increased the time and frequency of erratic movements proportionally to the concentration of the alarm substance (Speedie \& Gerlai, 2008). Piauçu, Leporinus macrocephalus, also showed erratic movements, followed by school cohesion and immobility after exposure to SE (Barbosa Júnior et al., 2012). The responses of silver catfish juveniles to PW and SE observed in the present study could be related to the same kind of behaviour. Another tropical freshwater fish, Rivulus hartii, demonstrated significant size-dependent trends in response to heterospecific alarm cues, with smaller individuals exhibiting antipredator responses and larger individuals shifting their behaviour to increased levels of activity consistent with a foraging, or predatory, response (Elvidge et al., 2010).

The overall response of the silver catfish juveniles to the increase in waterborne $\mathrm{NH}_{3}$ was the decrease of antipredator responses to $\mathrm{PW}$ or SE. No similar studies have been conducted on other species exposed to high levels of waterborne $\mathrm{NH}_{3}$. However, brown trout exposed to $1 \mathrm{mg} \mathrm{L}^{-1}$ $\mathrm{NH}_{3}$ exhibited predatory strikes, having a significantly lower distance, speed and turning radius and a lower number of prey captured than unexposed fish (Tudorache et al., 2008).

The decrease of the antipredator behaviour of silver catfish juveniles was proportional to the waterborne $\mathrm{NH}_{3}$ levels on some days and for some observed behaviours. The reason for this variation is not clear, but the effect of waterborne $\mathrm{NH}_{3}$ on the behaviour of common carp, Cyprinus carpio, also varied with the time of exposure (Israeli-Weinstein \& Kimmel, 1998). The loss of response to PW or SE of conspecifics by silver catfish juveniles exposed to waterborne $\mathrm{NH}_{3}$ does not imply that this species would be more vulnerable to predation because ammonia influences predator-prey interactions by disrupting predatory behaviour, changing the predator's intraspecific interactions and reducing the predation rate (Tudorache et al., 2008).

The results of this study suggest that silver catfish juveniles can use odour cues to identify predators and to identify skin extract from conspecifics. In addition, waterborne $\mathrm{NH}_{3}$ levels modify the antipredator response of this species.

\section{Acknowledgements}

B. B. and C. V. received CNPq (Conselho Nacional de Desenvolvimento Tecnológico -Brazil) research and undergraduate grants, respectively. P. W. received a MSc grant from CAPES (Coordenação de Aperfeiçoamento de Pessoal de Nível Superior, Brazil), and C. L. received an undergraduate grant from FAPERGS (Fundação de Amparo à Pesquisa no Estado do Rio Grande do Sul, Brazil).

\section{Literature Cited}

Barbosa Júnior, A., F. L. Alves, A. S. F. Pereira, L. M. Ide \& A. Hoffmann. 2012. Behavioral characterization of the alarm reaction and anxiolytic-like effect of acute treatment with fluoxetine in piauçu fish. Physiology \& Behavior, 105: 784-790.

Barreto, R. E., A. Barbosa Júnior, A. C. Giassi \& A. Hoffmann. 2010. The 'club' cell and behavioural and physiological 
responses to chemical alarm cues in the Nile tilapia. Marine and Freshwater Behaviour and Physiology, 43: 75-81.

Brown, G. E., J. C. Adrian Jr., N. T. Naderi, M. C. Harvey \& J. M. Kelly. 2003. Nitrogen oxides elicit antipredator responses in juvenile channel catfish, but not in convict cichlids or rainbow trout: conservation of the ostariophysan alarm pheromone. Journal of Chemical Ecology, 29: 1781-1796.

Brown, G. E., J. C. Adrian Jr., E. Smyth, H. Leet \& S. Brennan. 2000. Ostariophysan alarm pheromones: laboratory and field tests of the function significance of nitrogen oxides. Journal of Chemical Ecology, 26:139-154.

Brown, G. E. \& R. J. F. Smith. 1998. Acquired predator recognition in juvenile rainbow trout (Oncorhynchus mykiss): Conditioning hatchery reared fish to recognize chemical cues of a predator. Canadian Journal of Fisheries and Aquatic Sciences, 55: 611-617.

Chivers, D. P. \& R. J. F. Smith. 1998. Chemical alarm signalling in aquatic predator-prey systems: a review and prospectus. Ecoscience, 5: 338-352.

Chivers, D. P., B. D. Wisenden \& R. J. F. Smith. 1996. Damselfly larvae learn to recognize predators from chemical cues in the predator's diet. Animal Behaviour, 52: 315-320.

Clark, C. W. 1994. Antipredator behaviour and the asset-protection principle. Behavioral. Ecology, 5: 159-170.

Eaton A. D., L. S. Clesceri, E. W. Rice \& A. E. Greenberg. 2005. Standard methods for the examination of water and wastewater, $21^{\text {st }}$ edition, American Public Health Association, Springfield.

Elvidge, C. K, I. W. Ramnarine, J. G. J. Godin \& G. E. Brown. 2010. Size-mediated response to public cues of predation risk in a tropical stream fish. Journal of Fish Biology, 77: 1632-1644.

Israeli-Weinstein, D. \& E. Kimmel. 1998. Behavioral response of carp (Cyprinus carpio) to ammonia stress. Aquaculture, 165: 81-93.

Kiesecker, J. M., D. P. Chivers \& A. R. Blaustein. 1996. The use of chemical cues in predator recognition by western toad tadpoles. Animal Behaviour, 52: 1237-1245.

Kochhann, D., A. N. P. Benaduce, C. E. Copatti, K. R. Lorenzatto, M. F. Mesko, E. M. M. Flores, V. L. Dressler \& B. Baldisserotto. 2009. Protective effect of high alkalinity against the deleterious effects of chronic waterborne cadmium exposure on the detection of alarm cues by juvenile silver catfish (Rhamdia quelen). Archives of Environmental Contamination and Toxicology, 56: 770-775.

Lawrence, B. J. \& R. J. F. Smith. 1989. Behavioral response of solitary fathead minnows, Pimephales promelas, to alarm substance. Journal of Chemical Ecology, 15: 209-219.

Marcus, J. P. \& Brown, G. E. 2003. Response of pumpkinseed sunfish to conspecific chemical alarm cues: an interaction between ontogeny and stimulus concentration. Canadian Journal of Zoology, 81: 1671-1677.

Miron, D. S., A. G. Becker, V. L. Loro \& B. Baldisserotto. 2011. Waterborne ammonia and silver catfish, Rhamdia quelen: survival and growth. Ciência Rural, 41: 349-353.

Miron, D. S., B. Moraes, A. G. Becker, M. Crestani, R. Spanevello, V. L. Loro \& B. Baldisserotto. 2008. Ammonia and pH effects on some metabolic parameters and gill histology of silver catfish, Rhamdia quelen (Heptapteridae). Aquaculture, 277: 192-196.

Piper, R. G., I. B. McElwain, L. E. Orme, J. P. McCraren, L. G. Fowler, J. R. Leonard. 1982. Fish hatchery management, United States Department of the Interior, Fish and Wildlife Service, Washington, DC.
Pollock, M. S., R. J. Pollock \& D. P. Chivers. 2006. Effects of body size, body condition, and breeding state on responses to alarm cues by fathead minnows. Canadian Journal of Zoology, 84: 1351-1357.

Schulte, P. M., C. D. Moyes \& P. W. Hochachka. 1992. Integrating metabolic pathways in post-exercise recovery of white muscle. The Journal of Experimental Biology, 166: 181-195.

Scott, G. R., K. A. Sloman, C. Rouleau \& C. M. Wood. 2003. Cadmium disrupts behavioural and physiological responses to alarm substance in juvenile rainbow trout (Oncorhynchus mykiss). The Journal of Experimental Biology, 206: 1779-1790.

Shingles, A., D. J. McKenzie, E. W. Taylor, A. Moretti, P. J. Butler \& S. Ceradini. 2001. Effects of sublethal ammonia exposure on swimming performance in rainbow trout (Oncorhynchus mykiss). The Journal of Experimental Biology, 204: 2691-2698.

Speedie, N. \& R. Gerlai. 2008. Alarm substance induced behavioral responses in zebrafish (Danio rerio). Behavioural Brain Research, 188: 168-177.

Suski, C. D., J. D. Kieffer, S. S. Killen \& B. L. Tufts. 2007. Sub-lethal ammonia toxicity in largemouth bass. Comparative Biochemistry and Physiology A, 146: 381-389.

Tudorache, C., R. Blust \& G. Boeck. 2008. Social interactions, predation behaviour and fast start performance are affected by ammonia exposure in brown trout (Salmo trutta). Aquatic Toxicology, 90: 145-153.

Tudorache, C., R. A. O'Keefe \& T. J. Benfey. 2010. The effect of temperature and ammonia exposure on swimming performance of brook charr (Salvelinus fontinalis). Comparative Biochemistry and Physiology Part A, 156: 523-528.

Walker, J. A., C. K. Ghalambor, O. L. Griset, D. McKenney \& D. N. Reznick. 2005. Do faster starts increase the probability of evading predators? Functional Ecology, 19: 808-815.

Walsh, P. J., C. M. Veauvy, M. D. McDonald, M. E. Pamenter, L. T. Buck \& M. P. Wilkie. 2007. Piscine insights into comparisons of anoxia tolerance, ammonia toxicity, stroke and hepatic encephalopathy. Comparative Biochemistry and Physiology Part A, 147: 332-343.

Willette, T. 2001. Foraging behaviour of juvenile pink salmon (Oncorhynchus gorbuscha) and size-dependent predation risk. Fisheries Oceanography, 10: 110-131.

Wisenden, B. D., C. L. Binstock, K. E. Knoll, A. J. Linke \& B. S. Demuth. 2010. Risk-sensitive information gathering by cyprinids following release of chemical alarm cues. Animal Behaviour, 79: 1101-1107.

Wisenden, B. D., J. Karst, J. Miller, S. Miller \& L. Fuselier. 2008. Anti-predator behaviour in response to conspecific chemical alarm cues in an esociform fish, Umbra limi (Kirtland 1840). Environmental Biology of Fish, 82: 85-92.

Wood, C. M. 2001. Toxic responses of the gill. Pp. 1-89. In: Schlenk, D. W. \& W. H. Benson (Eds.). Target organ toxicity in marine and freshwater teleosts. v.1 Organs. Taylor and Francis, New York, NY.

Submitted August 23, 2011

Accepted April 6, 2012

Published June 29, 2012 